\title{
Distributional effects of higher natural gas prices in Russia
}

\begin{abstract}
This paper analyses the distributional effects of eliminating the implicit subsidy on natural gas consumption in Russia. The analysis is based on a computable general equilibrium model with multiple households and a detailed power generation sector. It is found that using additional government revenues from higher domestic gas prices to increase the income of low- and middle-income households could improve the welfare of these households and alleviate income inequality in Russia, e.g., total private consumption of the poorest decile could increase by $3 \%$. Nevertheless, the most efficient revenue-recycling policy would be to invest in the energy efficiency of buildings, which have the largest energy savings potential in Russia. In the long term, investing in the energy efficiency of buildings could reduce greenhouse gas emissions by 232 million tonnes of $\mathrm{CO}_{2}$ equivalent per year and increase the welfare of low- and middleincome households, e.g., total private consumption of the poorest decile increases by $1 \%$. It is also found that increasing the regulated domestic gas price could lead to windfall profits for non-Gazprom producers. Hence, to increase government revenues, the gas-price reform could be supplemented by an increase in the production or income tax in the gas sector.
\end{abstract}

Keywords: natural gas prices; Russia; income distribution; distributional effects; energy efficiency of buildings 


\section{Contents}

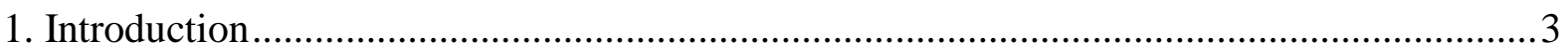

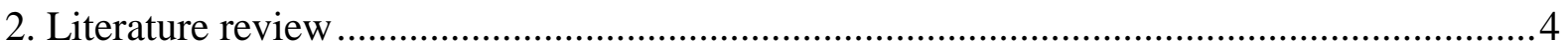

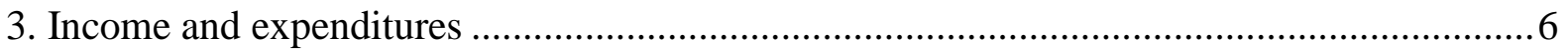

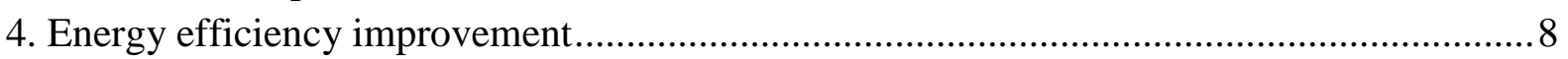

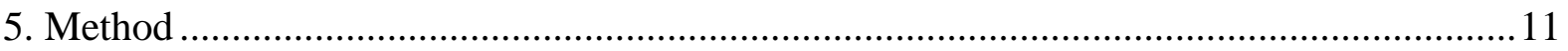

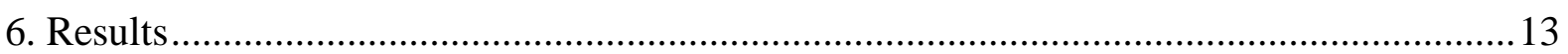

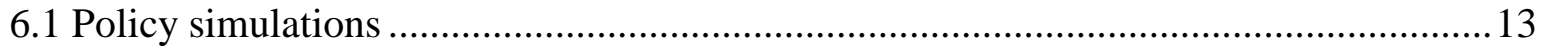

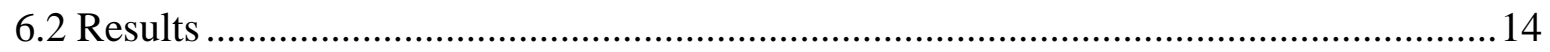

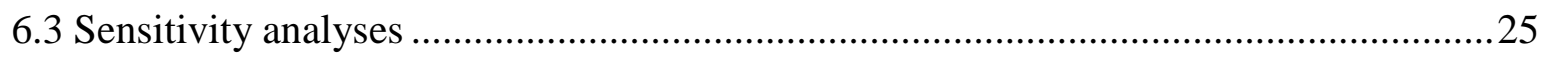

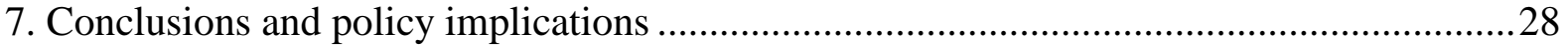

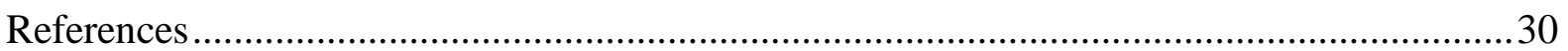




\section{Introduction}

Domestic natural gas (hereafter: gas) prices are regulated in Russia and they are substantially lower than export netback prices (the Russian Government, 2010; Gazprom, 2015). For example, in 2015, the average domestic price for gas sold by Gazprom in Russia was approximately $\$ 59 / 1,000 \mathrm{~m}^{3}$, whereas the average export netback price for gas exported to the Western Europe accounted for \$246/1,000 $\mathrm{m}^{3}$ (Gazprom, 2015). The regulation of domestic gas prices operates as an implicit subsidy. Although the Russian government has planned to increase the domestic price level in the long term (the Russian Government, 2010), the gasprice reform has been postponed for a long time because of increases in the oil price and the economic crisis.

Adverse income distributional effects and the loss in the competitiveness of energy-intensive industries are two main concerns related to an increase in gas prices in Russia. Because poor households spend a larger fraction of their income on gas, electricity, and heating, than rich households do, the poor are expected to be most adversely affected by an increase in energy prices. While subsidising the consumption of gas for poor households might be justified on the ground of income distribution, setting a low gas price for middle- and high-income households is very controversial. Moreover, the implicit gas subsidy implies a high efficiency cost, e.g., foregone export revenues. Increasing the regulated domestic gas price might raise substantial funds, which could be invested in energy efficiency. While having a large energy savings potential, in particular in residential and public buildings, the Russian economy certainly lacks private and public investments in energy efficiency. Nevertheless, it is unclear whether additional government revenues invested in energy efficiency would be sufficient to offset the adverse impacts on poor households. Increasing the domestic gas price could lead to windfall profits for non-Gazprom producers, meaning that the Russian government might not receive the entire profit resulting from higher gas prices. Moreover, higher domestic gas prices could induce significant impacts on factor income and prices of other commodities, as the Russian economy relies heavily on natural gas.

The objective of this paper is to analyse the distributional effects of eliminating the implicit gas subsidy in Russia. In many other similar studies (e.g., the literature on energy and environmental taxation), additional tax revenues are recycled into a reduction in distortionary taxes. In contrast, we compare two revenue-recycling policies, such as investments in the 
energy efficiency of buildings and transfers to low- and middle-income households. The results from policy simulations aim to shed light on how to design an optimal gas-price reform in Russia, which would encourage economic and energy efficiency, and, at the same time, would not exacerbate income inequality. Although this paper focuses on Russia and Russia's gas market, the results from our analysis could be relevant for many other countries that impose explicit or implicit energy subsidies, while having a large energy efficiency gap.

Because the gas sector plays an important role in the Russian economy, we need to take into account general equilibrium effects (e.g., changes in factor and output prices), which can be consistently depicted in a general equilibrium framework. Therefore, our analysis is based on a dynamic, multi-region, multi-sector computable general equilibrium (CGE) model. Due to a vital role of the power generation sector, which heavily relies on gas in Russia and hence and hence plays an important role in determining the incidence of the gas-price reform, we calibrated our model around an electricity-detailed extension of Version 9 of the Global Trade Analysis Project (GTAP9-Power) database (Aguiar et al., 2016; Peters, 2016). Furthermore, we disaggregated the representative household into a government account and 10 household groups. We also estimated demand elasticities for gas in Russia by using a panel-data regression model. The remainder of the paper is organised as follows. Section 2 gives a brief literature review. Section 3 provides some statistics on income and consumption expenditures by Russia’s private households. Section 4 reveals Russia’s energy savings potential and associated investment costs. Section 5 gives a brief description of the model and database. Section 6 deals with the results from policy simulations and sensitivity analyses. The last section presents the study's conclusions and a number of policy recommendations.

\section{Literature review}

Income distributional effects of an energy price reform or price volatility could vary by type of fossil fuel and region. While gasoline taxation in low- and middle-income countries tends to be progressive (Sterner, 2012), an increase in the prices of coal and natural gas typically tends to have regressive redistributive effects, because coal and natural gas are used as heating fuels in power generation. The poor typically spend a larger share of its income on gas, coal, electricity, and heating, than the rich do. Ersado (2012), using aggregate energy consumption data and a nationally representative household survey, analysed the redistributive effects of an increase in import prices for natural gas in Armenia. He showed that the gas price hike led to a 
significant increase in energy expenditures by poor households. Krauss (2016), using a regression model, estimated the poverty and distributional effects of a natural gas tariff reform in Armenia. He also found that a uniform increase in the consumer price of natural gas in Armenia could be rather regressive. On the contrary, Stockfisch (2007) showed that higher natural gas prices would be roughly progressive in the USA, as middle- and high income households consume relatively more gas and electricity than the poor does. Heyndrickx et al. (2012), using a CGE model, conducted an impact assessment of Russia’s incremental gas price reform. They found that an increase in gas prices in Russia would have a small adverse impact on income distribution among households, although they emphasise that revenue-recycling mechanisms have strong redistributive impacts.

Many numerical studies on energy and environmental taxation emphasise the relevance of the tax revenue recycling. Increasing a tax on fossil fuels would generate government revenues, which might effectively alleviate a possible regressive impact on income distribution (Sterner, 2012). Additional government tax revenues could be spent elsewhere in the economy, e.g., to reduce a distortionary tax. For example, Williams et al. (2014) found that using carbon tax revenues to reduce capital taxes is efficient but regressive, whereas lump-sum rebates or reducing labour income taxes are less efficient but much more progressive revenue recycling strategies. Wang et al. (2016) in their literature review paper also emphasised the trade-off between efficiency and equity of carbon taxation. Felder and Nieuwkoop (1996), using a static CGE model, found that adverse distributional effects of a carbon tax in Switzerland can be reversed when tax revenues are transferred to poor households in lump-sum form or used to reduce the marginal labour income tax rate.

While there is extensive literature on the distributional effects of carbon taxation and gasoline taxation, there are only a few empirical and numerical studies that analyse distributional effects of higher natural gas prices. Furthermore, the existing literature on distributional effects of carbon and gasoline taxation typically focuses on the same revenue-recycling schemes, such as lump-sum transfers, labour and capital income taxes, while redistributive effects of using additional government revenues to invest in energy efficiency improvement has not yet been analysed. However, it is likely that for many economies that have a large energy efficiency gap it would be more rational to invest in energy efficiency instead of reducing pre-existing taxes. Feng et al. (2010) pointed out that carbon tax revenues could be used to fund large-scale 
retrofitting of households, yet they did not provide any numerical analysis on this revenuerecycling policy.

\section{Income and expenditures}

The Russian Federal State Statistics Service (FSSS) provides data on income and consumption expenditures by income decile, which represents 10\% of the population each. Fig. 1 reveals the shares of income and consumption expenditure, and saving rates by Russia's income decile in 2015. The first income decile (d1) represents the poorest $10 \%$ of the population, and the last income decile (d10) comprises the richest $10 \%$ of the population, respectively. For example, the poorest income decile of Russia's households received almost 3\% of total income of all households in 2015, whereas the wealthiest income decline received approximately 31\%. Consequently, rich households have larger consumption expenditures and a higher saving rate compared to low-income households.

Fig. 1. Shares of income, consumption expenditures, and saving rate by income decile in 2015.

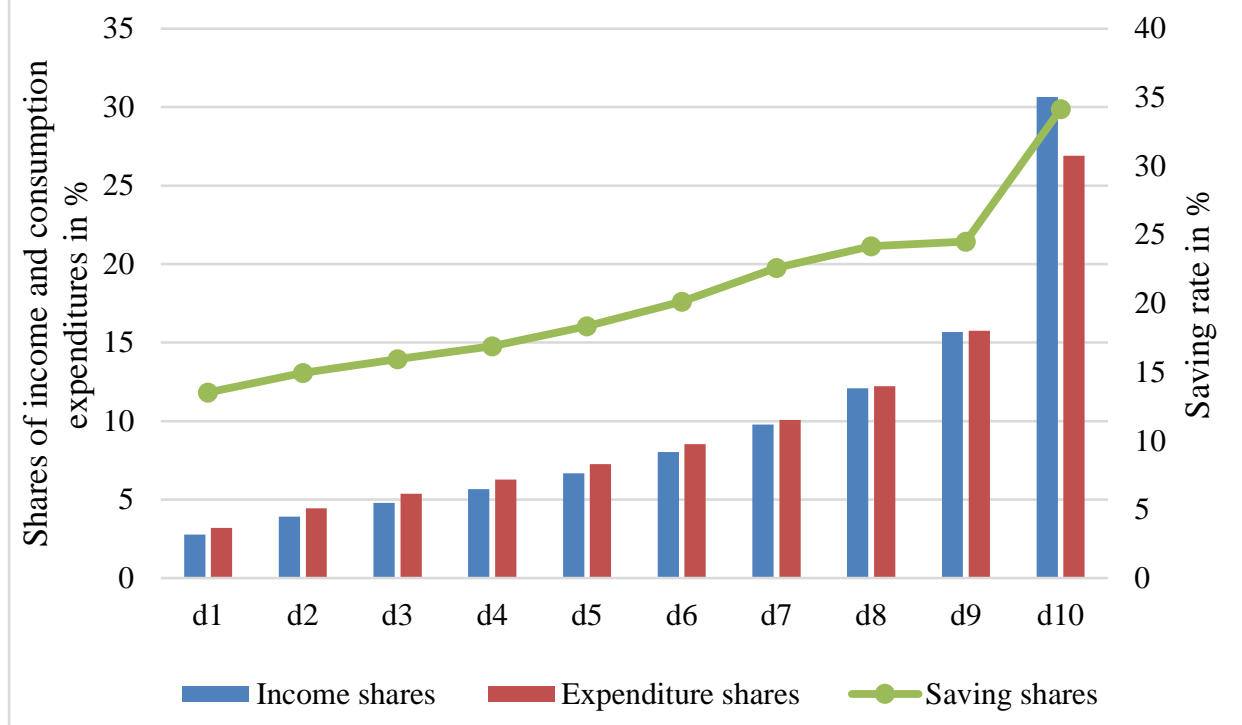

$\mathrm{d} 1, \mathrm{~d} 2 \ldots \mathrm{d} 10$ stand for income deciles, respectively.

Source: FSSS (2016)

The Russian economy is quite energy-intensive, heavily relying on gas consumption (Bashmakov, 2009; OECD/IEA, 2015). Thus, increasing the domestic gas price could have a significant impact on factor markets. The total income of households comprises income from labour, capital, and natural resources (i.e., resource rents). Fig. 2 shows the shares of factor 
income in total income by decile. ${ }^{1}$ Approximately 57\% of total income of the poorest income decile comes from unskilled labour, followed by skilled labour (41\%) and capital (2\%). In contrast, the share of capital income in total income of the richest income decile is substantially larger, accounting for approximately $42 \%$, while the shares of skilled and unskilled labour income are $47 \%$ and $11 \%$, respectively.

Fig. 2. Shares of factor income in total income by decile.

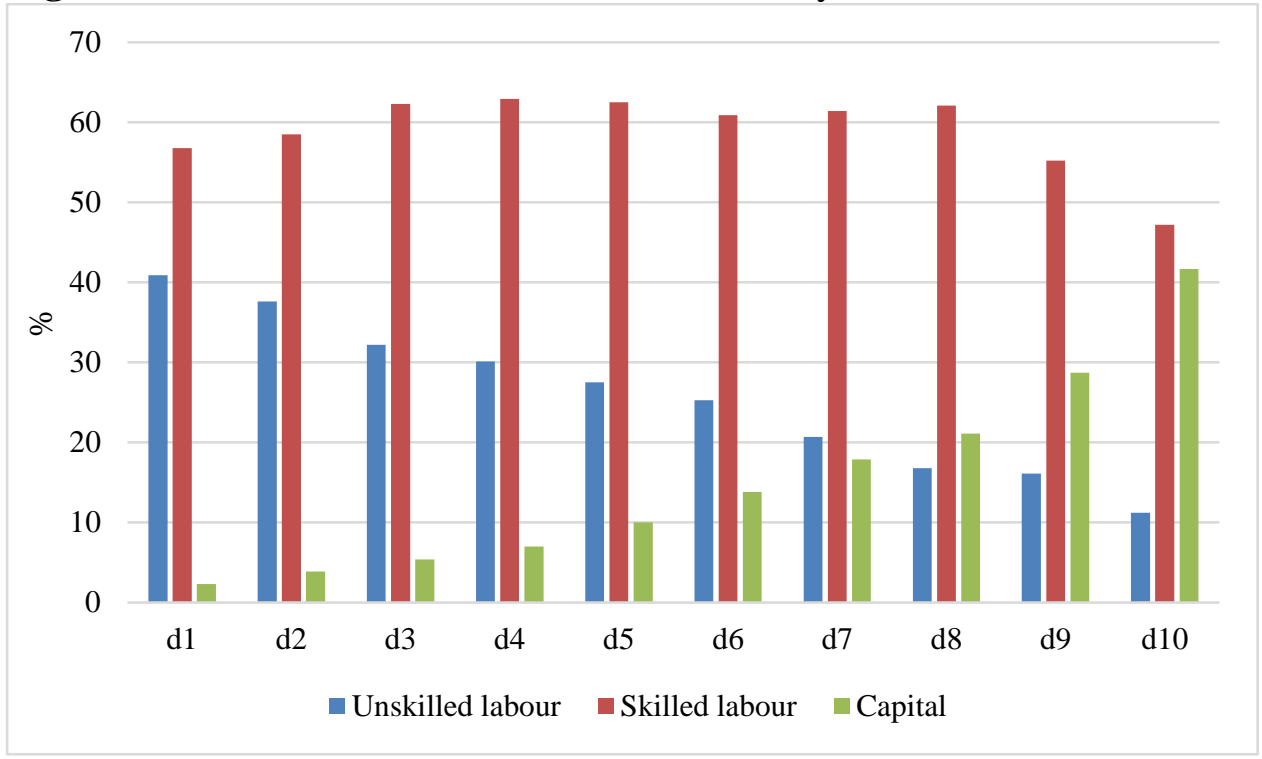

Source: Rutherford et al. (2004)

The structure of consumption expenditures differs by income decile. Poor households spend relatively more on food consumption compared to wealthy households; for example, the poorest income decile spent approximately $48 \%$ of its total consumption expenditure on food products in 2015, while the richest income decile spent only 27\% (Supplementary material, Appendix A). In contrast, wealthy households spent relatively more on services compared to poor households. Fig. 3 shows the expenditure shares of gas, electricity, and heating in total consumption expenditure by income decile in 2015. Low-income households spend a larger share of their income on gas, electricity, and heating than rich households do; for example, the expenditure shares of gas consumption in total consumption expenditures of the poorest income decile in 2015 accounted for $1.8 \%$, while for the richest income decile, these were $0.5 \%$. The expenditure shares of electricity and heating are substantially higher than of gas, and they are higher by low-income households than by wealthy households. Hence, an increase in gas and

\footnotetext{
${ }^{1}$ Although the factor income shares for Russia were estimated in 2004, it is unlikely that the structure of households' income has been changed very much.
} 
electricity prices will certainly have a direct regressive impact on income distribution among households in Russia.

Fig. 3. Expenditure shares of gas, electricity, and heating in total consumption expenditure by income decile in 2015.

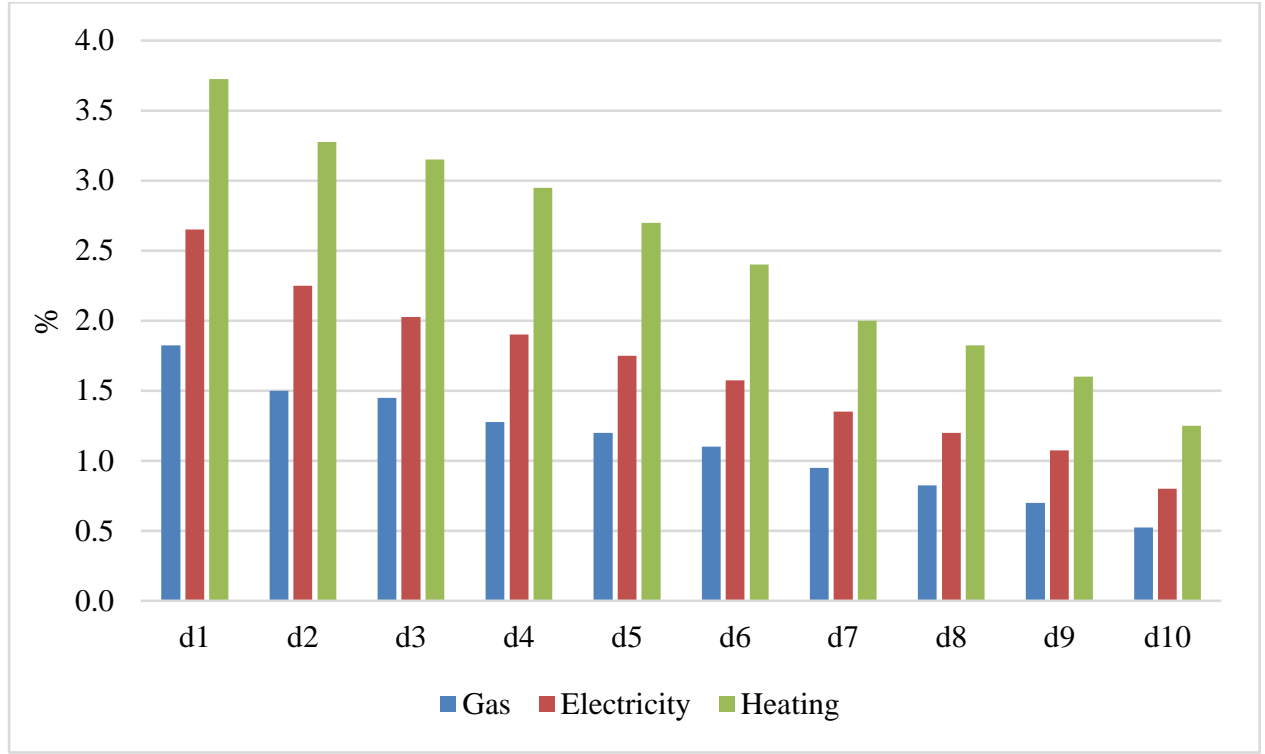

Source: FSSS (2016)

It should be noted that an increase in domestic gas prices might significantly affect production costs of other commodities and services, particularly gas- and electricity-intensive ones. For example, the transport sector, chemicals, and other manufacturing are large consumers of gas and electricity in Russia, and hence an increase in the gas price will likely lead to higher producer prices of these commodities and services. Because the indirect effects of the gas-price reform might also be important, we employ a general equilibrium model.

\section{Energy efficiency improvement}

Updated energy inefficient technologies are one of the main reasons for high energy and carbon intensity of the Russia economy. The World Bank and IFC (2014), based on Bashmakov (2009), provides estimates on sectoral energy savings potential and investment costs in Russia for 2005 and 2007, respectively (see Table 1). Residential and public buildings have the greatest technical energy savings potential, which could mainly be realised through energy efficiency improvement in space and water heating, e.g., wall insulation, efficient faucets, efficient windows, and window heat reflecting films. Installation of metering for space and water heating, could lead to a large reduction in energy consumption by encouraging changes in consumer behaviour. To stimulate energy efficiency improvement of buildings, the 
government can provide subsidies for modernisation and reparation of buildings as well as installation of widespread metering of energy use. Apart from financial support for improving energy efficiency, the government should encourage dissemination of information on energy efficiency and implement stricter energy efficiency standards. For more details on barriers and energy efficiency measures in Russia, see the report provided by the World Bank and IFC (2014).

Table 1. Technical energy saving potential and investment cost in Russia’s buildings.

\begin{tabular}{l|r|r|r|r|r}
\hline & Years & $\begin{array}{c}\text { Total energy } \\
\text { consumption } \\
\text { (in Mtoe) }\end{array}$ & $\begin{array}{c}\text { Technical } \\
\text { energy saving } \\
\text { potential (in } \\
\text { Mtoe) }\end{array}$ & $\begin{array}{c}\text { Technical } \\
\text { energy saving } \\
\text { potential (in \% } \\
\text { to energy } \\
\text { consumption) }\end{array}$ & $\begin{array}{c}\text { Incremental } \\
\text { investment } \\
\text { cost (in billion } \\
\text { USD) }\end{array}$ \\
\hline \multirow{3}{*}{ Buildings } & 2005 & 144.5 & 68.6 & 47.5 & - \\
& 2007 & - & - & - & $25-50$ \\
Total & 2017 & - & - & 42 & $59-118$ \\
\hline & 2005 & 654 & - & 44.9 & - \\
& 2007 & - & - & - & 320 \\
\hline
\end{tabular}

Source: based on the World Bank and IFC (2014)

The estimated technical energy saving potential in buildings in 2005 accounted for $47.5 \%$ of total energy consumption in buildings. According to the IEA database (IEA, 2016), total energy intensity of Russia’s GDP declined by approximately 2\% per year from 2005 to 2014. However, the main driver of energy efficiency improvement was a structural change. Bashmakov and Myshak (2014) estimated that the annual average contribution of technological change to GDP energy intensity reduction was approximately 1\% in 2009-2012. Given the assumption that the annual reduction in energy intensity in buildings from 2005 to 2017 was at 1\%, the technical energy saving potential in buildings in 2017 accounted for approximately $42 \%$ of total energy consumption in buildings. At the same time, the estimated investment cost required to realise the technical energy savings potential in buildings also changed due to inflation in Russia. According to the Russian Federal State Statistics Service (FSSS, 2016a), the annual average 
inflation rate in Russia from 2007 to 2017 was approximately $9 \% .^{2}$ This implies that the investment cost in buildings in 2017 was approximately \$59-118 billion.

Although Russia's energy saving potential is large, investing in energy efficiency is limited by fiscal constraints. Private sector is unable to undertake such large-scale investments, while the government faces a budget constraint. Private investments in the energy efficiency of residential buildings are also limited due to households' low income and the principle-agent problem, i.e., developers typically do not have incentives to improve energy efficiency. At the same time, increasing the regulated domestic gas price could raise a large amount of public funds, which could be invested in the energy efficiency of residential and public buildings.

Our calculations show that to reduce total energy consumption in buildings by $42 \%$, it is required to invest approximately $\$ 90$ billion in energy efficiency. Fig. 4 reveals a hypothetical relationship between investments and energy savings. An elasticity between investment and energy efficiency improvement of 1 implies that a $1 \%$ increase in investments leads to a $1 \%$ increase in energy efficiency, i.e., the marginal abatement cost is constant. A higher elasticity implies that a moderate energy efficiency improvement could be achieved at relatively low costs, yet it becomes more expensive with the more ambitious is the target of energy efficiency improvement. Due to a lack of data, we assume an elasticity of 1.5, i.e., an increase in energy efficiency of $1 \%$ implies an increase in investments of $1.5 \%$.

\footnotetext{
${ }^{2}$ It should be noted that since 2007, the Russian currency depreciated relative to the USD. In 2007, the exchange rate was 26 Rouble/USD, while in 2016, it was approximately 70 Rouble/USD, i.e., the annual average increase in the exchange rate was approximately $12 \%$. Deprecation of the currency, among other things, leads to inflation. Hence, by scaling the estimated investment cost for 2007 by the inflation rate, we implicitly take into account the deprecation of the Russian Rouble.
} 
Fig. 4. Investments in energy efficiency of buildings and energy savings in 2017.

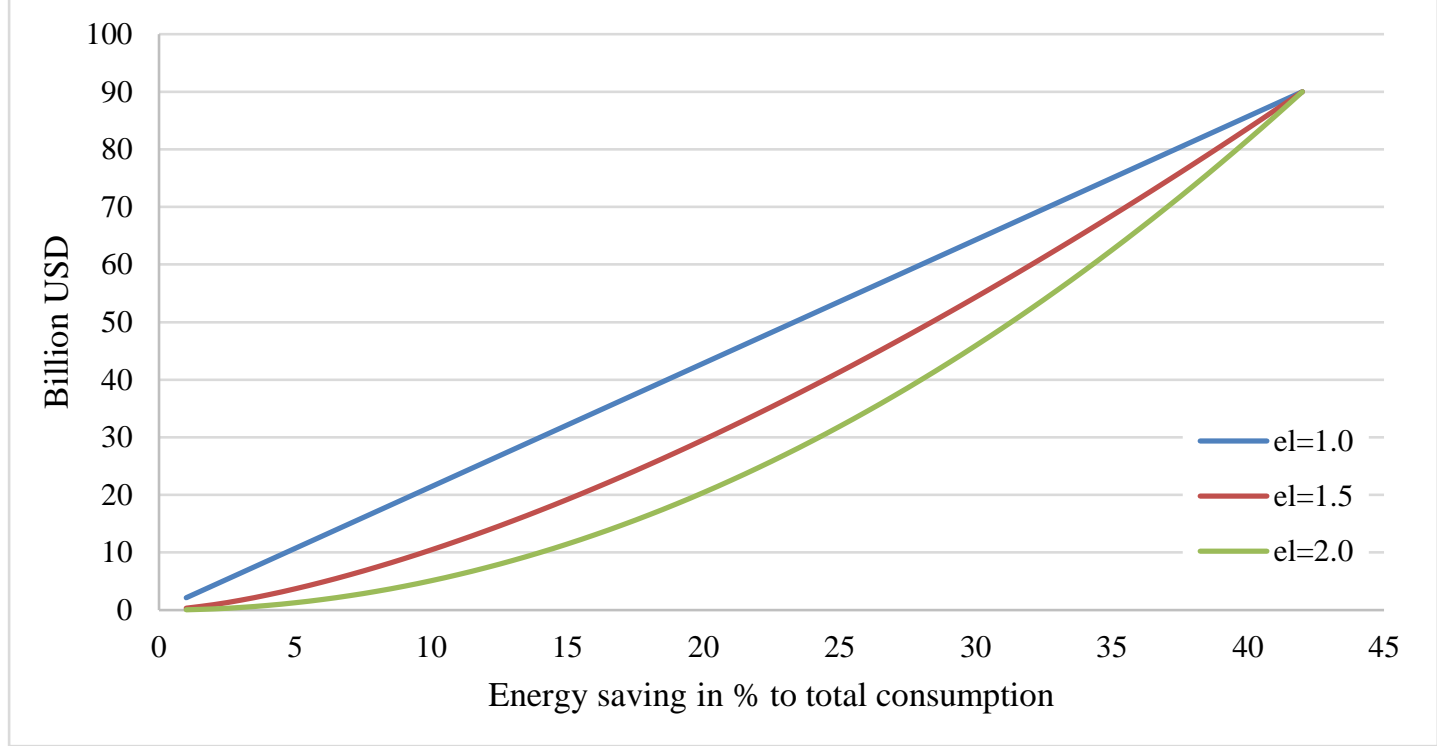

Source: own calculations based on the World Bank and IFC (2014)

\section{Method}

Our analysis is based on a dynamic, multi-region, multi-sector CGE model, GRACE (Aaheim and Rive, 2005). CGE models have a rich specification and a theoretically consistent foundation, and hence they are widely used for macroeconomic economic analyses, especially when interactions between factor and output markets and trade effects are crucial. The informal description of the model is presented in Supplementary Material, Appending B. The model is calibrated around an electricity-detailed extension of Version 9 of the GTAP9-Power database, which provides data on 140 regions and 68 commodities (Aguiar et al., 2016; Peters, 2016). We aggregated all commodities and services into 23 commodities. Since our analysis focuses on Russia, we aggregated all other countries and regions into the rest of the world (RoW). We also aggregated all power generation technologies depicted in the GTAP9-Power database into gas-fired, coal-fired, nuclear, hydro, and other renewables. Furthermore, for the purpose of analysis, based on the Russian Federal State Statistics Service, we disaggregated the regional household into a government account and 10 household groups (i.e., income declines). More technically, we use the shares of income and consumption expenditures, and savings rates, which are presented in Section 2, to distribute income, savings and consumption expenditures among income deciles. For more details on the disaggregation procedure, see Supplementary material, Appendix C. 
We found some inconsistency between the energy tax system depicted in the GTAP9-Power database and the Russian Tax Code. For example, according to the GTAP9-Power database, the export tax on gas in Russia is over 300\%, whereas according to the Russian Tax Code the export tax rate on natural gas has been set to 30\%. Moreover, the GTAP9-Power database shows high sale taxes on gas consumption, whereas domestic gas prices are administratively regulated in Russia, and they are substantially lower than export netback prices (Gazprom, 2014). In other words, domestic consumers of gas are implicitly subsidised in Russia through low consumer prices. Therefore, we adjust the pre- and post-taxes values in the GTAP9-Power database to correct for the appropriate export tax rate on gas and to incorporate domestic gas subsidies, i.e., the implicit subsidy on domestic gas consumption is explicitly depicted. We reduced the export tax rate for gas to $30 \%$ and incorporated a subsidy on domestic gas consumption of $40 \%$. For more details on the tax adjustment procedure, see Supplementary material, Appendix D.

To model investments in the energy efficiency of buildings, additional government revenues from increasing the regulated domestic gas price are used to increase the government demand for investment goods. At the same time, we proportionally increase the energy efficiency of households' energy consumption (see Section 4).

To track income transfers from the gas sector, we incorporated an enterprise account that collects capital and resource income from the gas sector, while the domestic gas subsidy reduces the enterprise's income of the gas sector. Net enterprise's income is then distributed between the government and private investors. In 2015, the state-run company, Gazprom, produced approximately $66 \%$ of total domestic production, and the remainder was produced by independent private gas producers. It should also be noted that the Russian government has only $50 \%$ of total property rights in Gazprom, while the remainder belongs to private investors. Therefore, we assumed that $33 \%$ of net enterprise income is distributed to the government, whereas the remainder is distributed to private households, proportionally to capital income. The gas price regulation operates as an implicit tax on enterprise's income. Consequently, increasing the regulated domestic gas price will increase the enterprise's income, thereby increasing government revenues and income of private households. 


\section{Results}

\subsection{Policy simulations}

In this analysis, we simulate the elimination of the implicit subsidy on domestic gas consumption by increasing the regulated domestic gas price under different revenue-recycling strategies. The implicit domestic gas subsidy rate is estimated to be approximately $40 \%$ of the producer price. This subsidy rate depicts the wedge between the marginal production cost and the domestic consumer gas price. ${ }^{3}$ We run our dynamic CGE model from 2011 to 2019, where the gas-price reform is implemented in 2017. Increasing the regulated domestic gas price will result in higher government revenues because it will increase the revenue of the state-run company, Gazprom. In the academic literature on climate mitigation policies, many economists suggest to use revenues from energy or environmental taxes to reduce distortionary taxes. In Russia, the value added tax rate on standard goods and services accounts for $18 \%$, the personal labour income tax rate is $13 \%$, the capital gains tax rates vary from $15 \%-30 \%$, and the corporate income tax rate is $20 \%$. The tax rates are not very high, meaning that consumption and income are unlikely to be overtaxed in Russia. ${ }^{4}$ At the same time, Russia's buildings and industries have a large energy savings potential. Therefore, using additional government revenues to invest in energy efficiency might be the most effective and efficient policy for Russia. Our main policy simulations are as follows:

1) Transfers: the elimination of the implicit subsidy on domestic gas consumption when additional government revenues are returned to low- and middle-income households (i.e., income deciles 1-6) in a lump-sum form.

2) IEE of buildings: the elimination of the implicit subsidy on domestic gas consumption when additional government revenues are earmarked for investments in the energy efficiency of buildings by low- and middle-income households (i.e., income deciles 16).

In practice, the "Transfers" scenario could imply many different revenue-recycling options, such as an increase in wages for public sector employees (e.g., schoolteachers and doctors)

\footnotetext{
${ }^{3}$ Even after the elimination of the domestic gas subsidy of $40 \%$, the domestic gas price still remains lower than the average export netback price.

${ }^{4}$ Many developed countries impose much higher taxes on labour income.
} 
and/or pension. Many pensioners and public sector employees belong to low- and middleincome household groups. The "IEE of buildings" scenario imply government subsidies stimulating modernisation and reparation of existing buildings as well as installation of widespread metering of energy consumption.

To test the robustness of the results, we conduct several sensitivity analyses with respect to key parameters and assumptions:

- International capital mobility

- Price elasticity of households’ demand for gas

- Price elasticity of gas supply

- Substitution elasticity among power generation technologies

- Income elasticities of gas demand

\subsection{Results}

\section{Consumer prices}

The welfare effects and incidence of the gas-price reform are determined through changes in relative commodity and factor prices. Table 2 reveals the changes in consumer prices of the gas-price reform. ${ }^{5}$ Overall, the changes in consumer prices under the two revenue-recycling strategies are very similar. The gas-price reform leads to higher consumer prices for gas and electricity, as the Russian power generation sector heavily relies on natural gas. For example, the increase in the consumer price for gas accounts for approximately 56\%, whereas the electricity price rises by $12 \%$. While the increase in the consumer price of electricity is relatively smaller than of gas, households spend a larger share of their total income on electricity and heating than on gas. Furthermore, there is a moderate increase in the consumer price of chemicals, whereas consumer prices of agricultural goods and some services decrease due to lower production costs. The changes in consumer prices of many commodities and services are negligible, i.e., less than $1 \%$.

\footnotetext{
${ }^{5}$ These changes in real consumer prices should be interpreted as average changes in consumer prices in Russia, which might differ by region.
} 
Table 2. Percentage changes of real consumer prices compared to the reference scenario in 2017.

\begin{tabular}{lcc}
\hline & Transfers & $\begin{array}{c}\text { IEE of } \\
\text { buildings }\end{array}$ \\
\hline Agriculture & -0.6 & -0.5 \\
Communication & -0.9 & -0.6 \\
Construction & -0.9 & -0.4 \\
Chemicals & 1.2 & 1.4 \\
Electricity & 12.2 & 11.8 \\
Food & -0.6 & -0.4 \\
Gas & 55.6 & 55.6 \\
Manufacturing & 0.0 & 0.3 \\
Motor vehicles & -0.5 & -0.2 \\
Business services & -1.0 & -0.7 \\
Financial services & -1.4 & -1.1 \\
Public administration & -1.0 & -0.6 \\
Oil products & -0.3 & -0.1 \\
Recreation services & -0.7 & -0.4 \\
Textiles & -0.7 & -0.4 \\
Trade services & -1.2 & -0.9 \\
Transport & 0.1 & 0.4 \\
Water & 0.3 & 0.4 \\
\hline CPI & 0.8 & 0.5 \\
\hline
\end{tabular}

The impact of the gas-price reform on the CPI differs by household group due to different consumption expenditure shares. Fig. 5 reveals the changes in the CPI by income decile in 2017. For example, the CPI of the poorest income decile increases by almost $1.6 \%$, whereas for the richest income decile, it increases by only approximately $0.4 \%$. 
Fig. 5. Percentage changes of the CPI by income decile compared to the reference scenario in 2017.

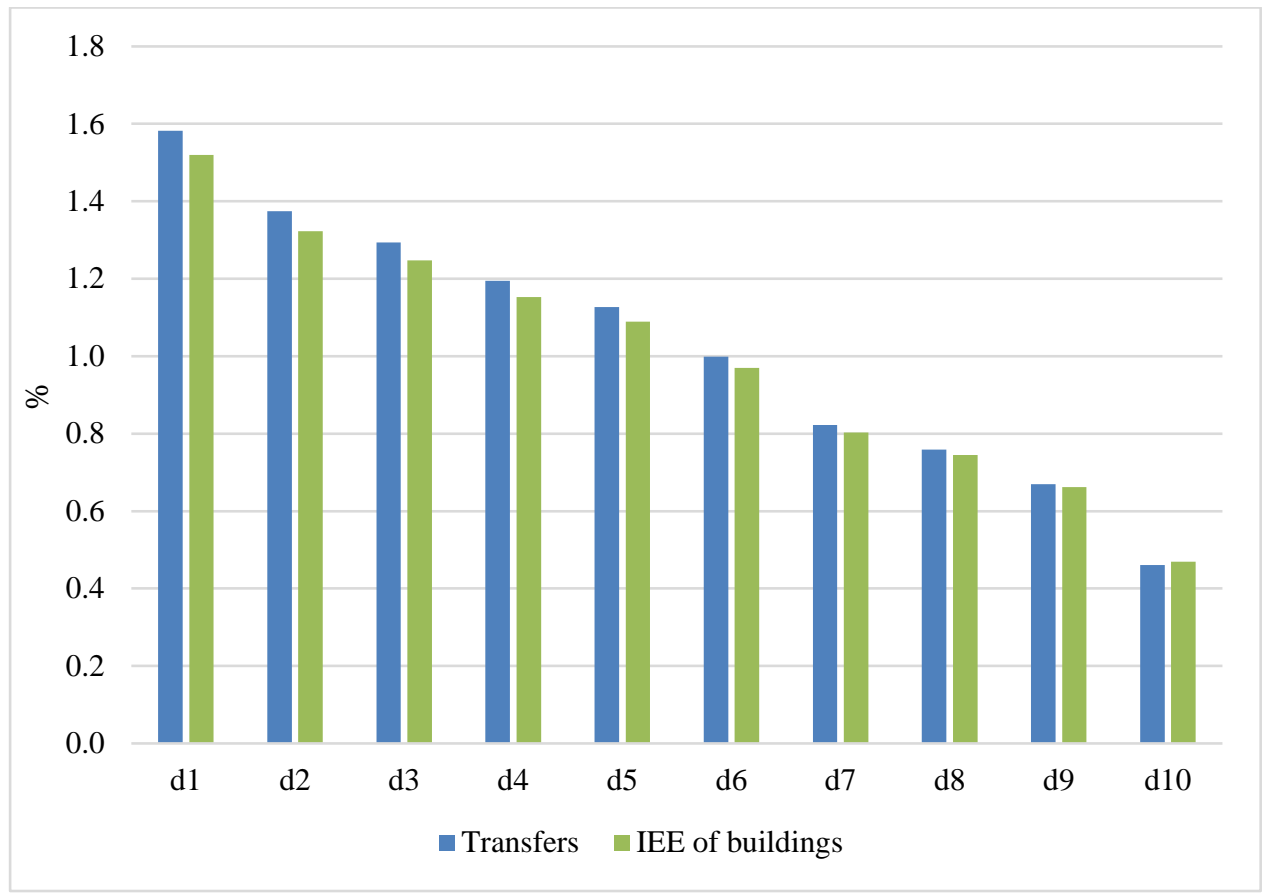

\section{Factor income}

Table 2 reveals that the changes in consumer prices of commodities and services (excluding gas and electricity) are moderate. Hence, we could use a partial equilibrium model; however, the impacts of the gas-price reform on factor markets and households' income, which also drive the changes in households' private consumption, should not be neglected. Fig. 6 illustrates the changes in total real factor income, showing that these impacts are significant. When additional government revenues from increased domestic gas prices are returned to low- and middleincome households in a lump-sum form, the gas-price reform leads to reductions in wages for skilled and unskilled labour and returns to capital and natural resources, thereby implying a lower factor income of households. ${ }^{6}$ Intuitively, increasing energy prices makes Russia’s producers of energy-intensive commodities and services less competitive in domestic and export markets, thereby leading to lower returns to production factors. The relative reductions in the wages are stronger than the reduction in the return to capital, and hence, the decreases in the total real factor income of low-income households are more pronounced than those of highincome households. Using additional government revenues to invest in the energy efficiency

\footnotetext{
${ }^{6}$ Here, the return to natural resources is a weighted average return of returns to natural resources used by agriculture, minerals, crude oil, coal, natural gas, hydropower, and renewables.
} 
of buildings results in a stronger reduction in the return to land and natural resources, while the decreases in the wages for skilled and unskilled labour, and the return to capital are slightly less pronounced compared to the "Transfers" scenario. Obviously, increasing the regulated domestic gas price alone would have a regressive impact on income distribution in Russia because of a large increase in the CPI by poor households and a reduction in the wages for skilled and unskilled labour, the main income source of low- and middle-income households.

Fig. 6. Percentage changes of total real factor income compared to the reference scenario in 2017.

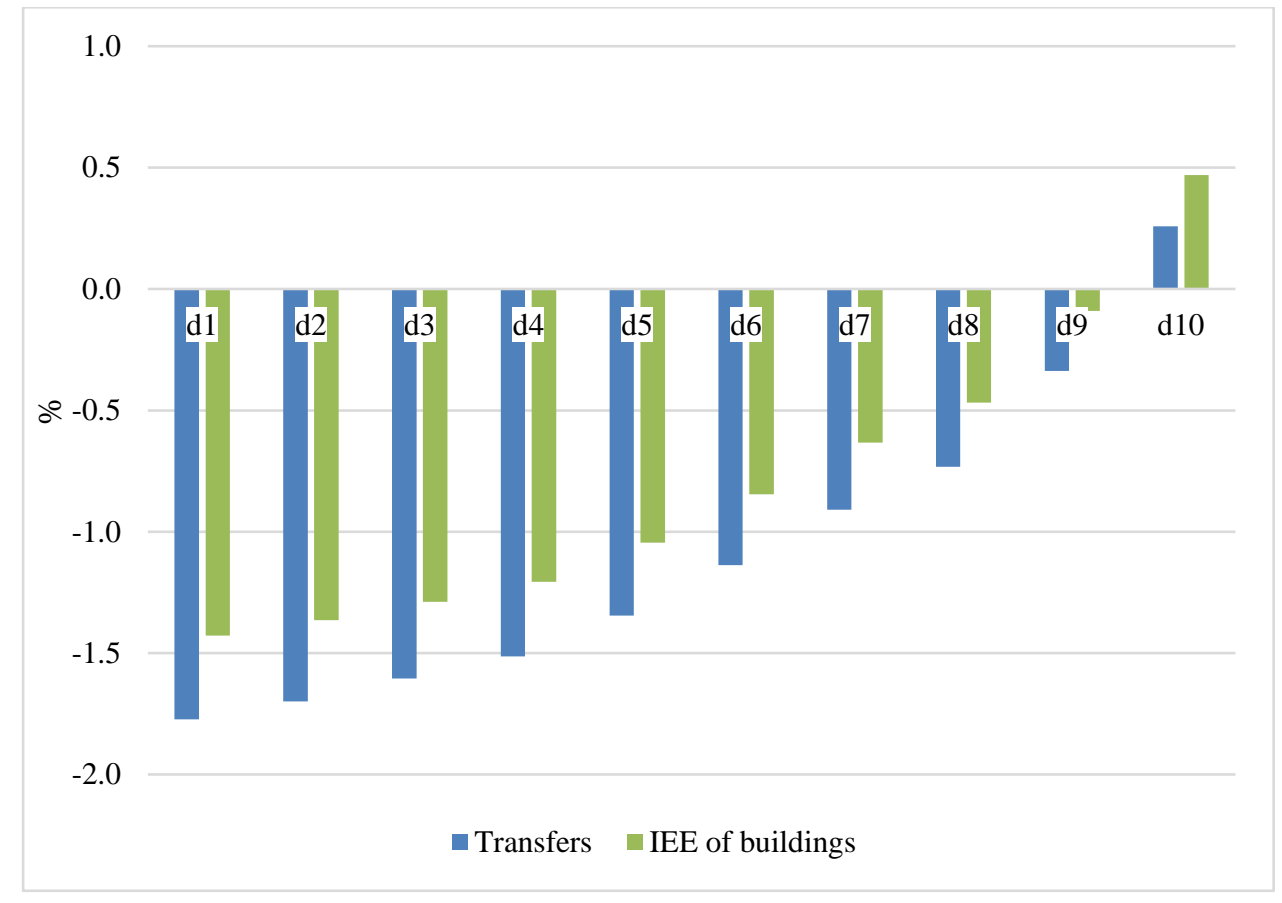

Nevertheless, the revenue-recycling effect plays a crucial role in determining the overall distributional effect of the gas-price reform. Fig. 7 reveals the changes of total real income by decile under the two revenue-recycling strategies. In the "Transfers" scenario, despite the reductions in the wage rates, the total income of low- and middle-income households increases due to higher government transfers. For example, the real income of the poorest income decile increases by almost $4 \%$. In contrast, using additional government revenues to invest in the energy efficiency of buildings leads to reductions in the total income of low- and middleincome households because of decreased wages for skilled and unskilled labour; for example, the real income of the poorest income decile falls by approximately $1.4 \%$. 
Fig. 7. Percentage changes of total real income by decile compared to the reference scenario in 2017.

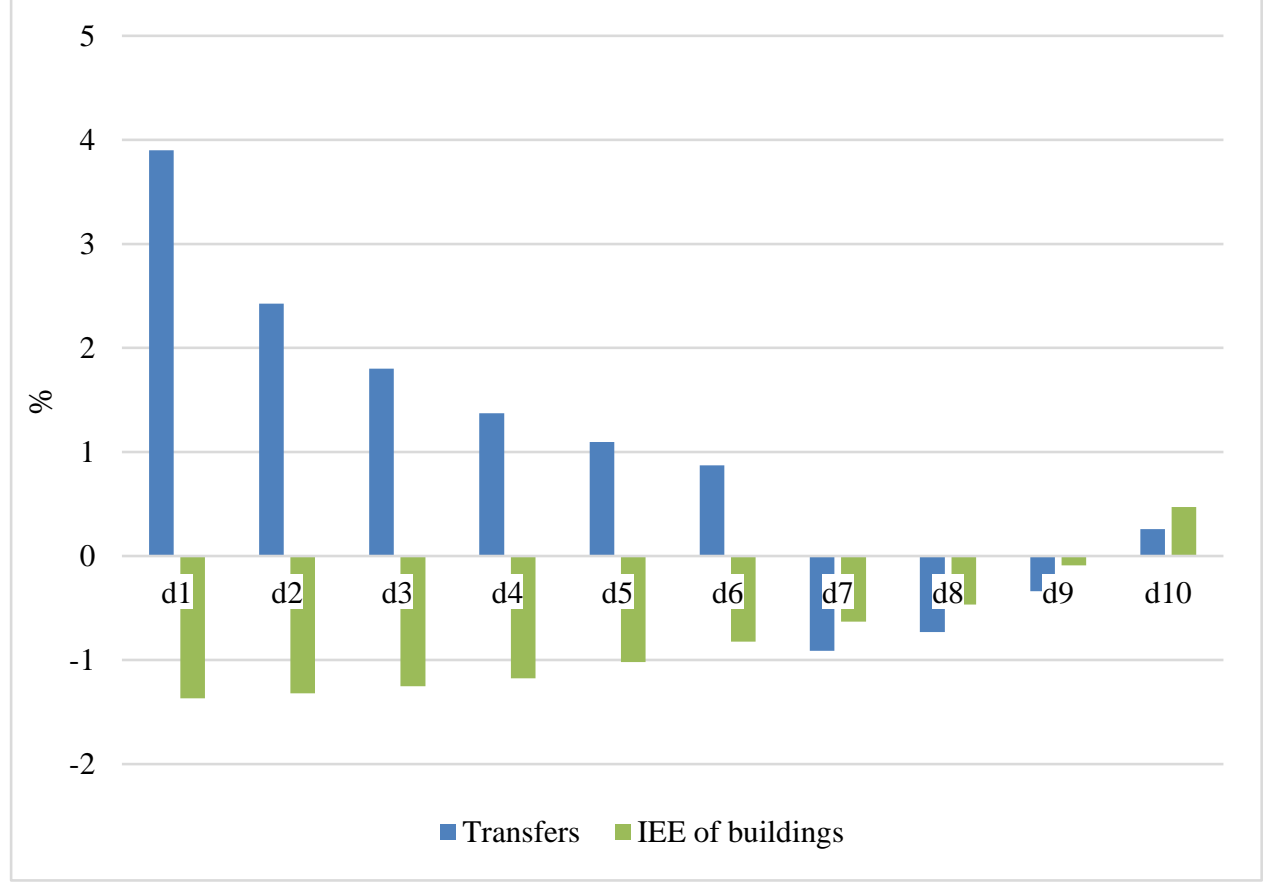

It is interesting that in both scenarios, the total income of wealthy households increases. This is because of the so-called windfall profit. Since the domestic demand for gas is inelastic, an increase in the regulated domestic gas price leads to higher profits for the state-run company, Gazprom, as well as private non-Gazprom producers.

\section{Private consumption}

Food products and trade services have the largest shares in total private consumption, and hence, private welfare is strongly affected by changes in prices of these commodities and services. Table 3 shows the changes of private consumption of all households. ${ }^{7}$ In all policy simulations, increasing the regulated domestic gas price leads to a lower private consumption of gas, electricity, and chemicals, driven by increased consumer prices of these commodities. In the “Transfers" scenario, due to a higher income, consumption of many commodities and services increases. In contrast, in “IEE of buildings” scenario, because of households' lower income and increased energy prices, consumption of agricultural and food products and some services decreases, although the changes in consumption of many commodities and services are moderate, i.e., less than $1 \%$. Furthermore, investing in the energy efficiency of buildings results

\footnotetext{
${ }^{7}$ These changes in private consumption are average changes in private consumption in Russia, which in turn might differ by region.
} 
in a larger reduction in private consumption of gas and electricity than in the "Transfers" scenario. It should also be noted that the changes in consumption of commodities and services differ by decile due to different changes in income. For the sake of brevity, we do not report those changes, yet below we discuss the changes in total private consumption by income decile.

Table 3. Shares of consumption expenditures and percentage changes of private consumption of all household groups compared to the reference scenario 2017.

\begin{tabular}{lccc}
\hline & $\begin{array}{r}\text { Expenditure } \\
\text { shares }\end{array}$ & Transfers & $\begin{array}{r}\text { IEE of } \\
\text { buildings }\end{array}$ \\
\hline Agriculture & 5 & 0.6 & -0.4 \\
Communication & 1 & 1.0 & -0.5 \\
Construction & 1 & 0.6 & -0.4 \\
Chemicals & 3 & -1.5 & -2.1 \\
Electricity & 5 & -2.3 & -8.2 \\
Food & 15 & 0.5 & -0.6 \\
Gas & 1 & -12.1 & -17.7 \\
Manufacturing & 6 & -0.2 & -1.0 \\
Motor vehicles & 4 & 0.3 & 0.1 \\
Business services & 7 & 0.6 & 0.1 \\
Financial services & 1 & 1.2 & 0.3 \\
Public administration & 5 & 0.8 & -0.1 \\
Oil products & 3 & 1.7 & 0.3 \\
Recreation services & 3 & 0.2 & -0.3 \\
Textiles & 4 & 0.5 & -0.4 \\
Trade services & 28 & 0.9 & 0.4 \\
Transport & 9 & -0.2 & -1.2 \\
Water & 2 & -0.1 & -1.5 \\
\hline
\end{tabular}

\section{Welfare by income decile}

Overall, the elimination of the implicit domestic gas subsidy by increasing the regulated domestic gas price has a positive welfare effect in Russia. This is in line with the theory of welfare economics because reducing a distortionary subsidy tends to result in welfare gains. Table 4 reveals the changes in real gross domestic product (GDP), greenhouse gas (GHG) emissions, and the welfare effects measured by equivalent variation (EV). Since demand for natural gas is inelastic and Russia's domestic consumption of gas is large, increasing the regulated domestic gas price provides a substantial amount of additional government revenues. The opportunity cost of supplying gas to the domestic market equals the export price of gas, which is considerably higher than domestic gas prices (i.e., foregone export revenues). The results from policy simulations show that the gas-price reform increases government revenues by approximately $\$ 14$ billion per year, which is approximately 19\% of Russia’s sovereign 
welfare fund in 2016 (Ministry of Finance of Russia, 2016). ${ }^{8}$ Furthermore, increasing the regulated domestic gas price in Russia results in a large reduction in GHG emissions. While in the "Transfers" scenario, the reduction in GHG emissions is mainly achieved through lower domestic consumption of gas, in the "IEE of buildings" scenario, a large reduction in GHG emissions is achieved through improvement in the energy efficiency of buildings. As a result, the reduction in GHG emissions in the "IEE of buildings" scenario is significantly larger than in the "Transfers" scenario. Due to a lack of information and coordination, and the principleagent problem, increasing the real income of low- and middle-income households alone might not achieve a desirable energy efficiency improvement. It should also be noted that the welfare gains from the gas-price reform are likely to be underestimated since our analysis does not take into account positive environmental and health impacts associated with a reduction in GHG emissions and local air pollution.

Table 4. Total welfare and emission effects compared to the reference scenario.

\begin{tabular}{lcc}
\hline & Transfers & $\begin{array}{r}\text { IEE of } \\
\text { buildings }\end{array}$ \\
\hline $\begin{array}{l}\text { EV (in \% to base } \\
\text { household expenditures): }\end{array}$ & & \\
2017 & 0.2 & 0.0 \\
2018 & 0.2 & 0.1 \\
2019 & 0.2 & 0.2 \\
\hline GDP (in \%): & & \\
2017 & 0.4 & 0.6 \\
2018 & 0.4 & 0.8 \\
2019 & 0.4 & 0.9 \\
\hline GHG emissions (in million & & \\
tonnes of CO 2 equivalent): & & \\
2017 & -177 & -206 \\
2018 & -173 & -220 \\
2019 & -170 & -232 \\
\hline
\end{tabular}

Although the gas-price reform results in an overall welfare gain, welfare effects significantly differ by household group. Fig. 8 shows the private welfare effects of the gas-price reform by income decile. The welfare effects are measured as changes in total private consumption, which also could be interpreted as the EV calculated in per cent to base household expenditures. When additional government revenues from increasing the domestic gas price are used to raise the income of low- and middle-income households, private welfare of these households increases.

\footnotetext{
${ }^{8}$ In 2016, Russia’s sovereign welfare fund accounted for approximately $\$ 72$ billion.
} 
For example, total private consumption of the poorest income decile increases by almost 3\%, whereas for the richest income decile, it increases by approximately $0.5 \%$. In other words, additional government revenues are more than sufficient to offset the adverse effect of increased energy prices, so the increase in total income outweighs the increase in the CPI by income decile. On the contrary, total private consumption of rich households (i.e., income deciles 7-9) falls because of a lower factor income, particularly a lower wage for skilled labour and a lower return to capital, and increased energy prices. Nevertheless, total private consumption of the richest income decile increases slightly due to the windfall profits in the gas sector, as explained above.

Fig. 8. Percentage changes of total private consumption by income decile compared to the reference scenario in 2017.

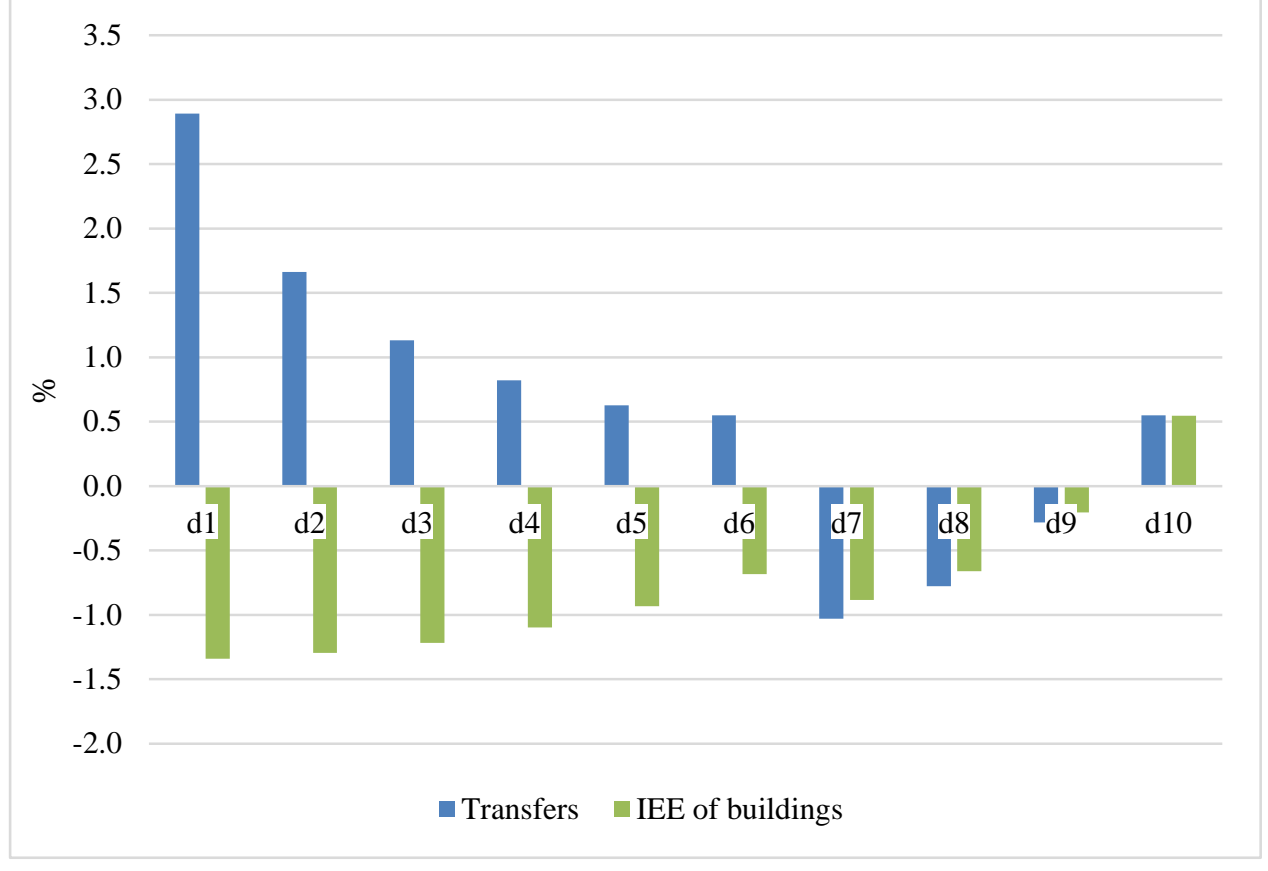

Although using additional government revenues to increase the income of low- and middleincome households' results in welfare gains for poor households, investing additional revenues in the energy efficiency of buildings has an adverse impact on low- and middle-income households in 2017. For example, total private consumption of the poorest income decile decreases by approximately $1.3 \%$. Nevertheless, the overall impact of the gas-price reform should be considered in a dynamic perspective. In the first year, additional government revenues are insufficient to mitigate the increase in energy prices. However, in subsequent years, the revenue from higher gas prices could further be invested in the energy efficiency of buildings, providing additional efficiency gains. Fig. 9 compares the changes in total private 
consumption in 2017, 2018 and 2019, showing that investing in the energy efficiency of buildings will lead to an increase in total private consumption of low- and middle-income households in 2019. For example in 2019, total private consumption of the richest income decile will increase by $0.9 \%$, and the energy efficiency of buildings will increase by $36 \%$, i.e., the technical energy saving potential is almost realised.

Fig. 9. Percentage changes of total private consumption by income decile compared to the reference scenario in 2017, 2018, and 2019.

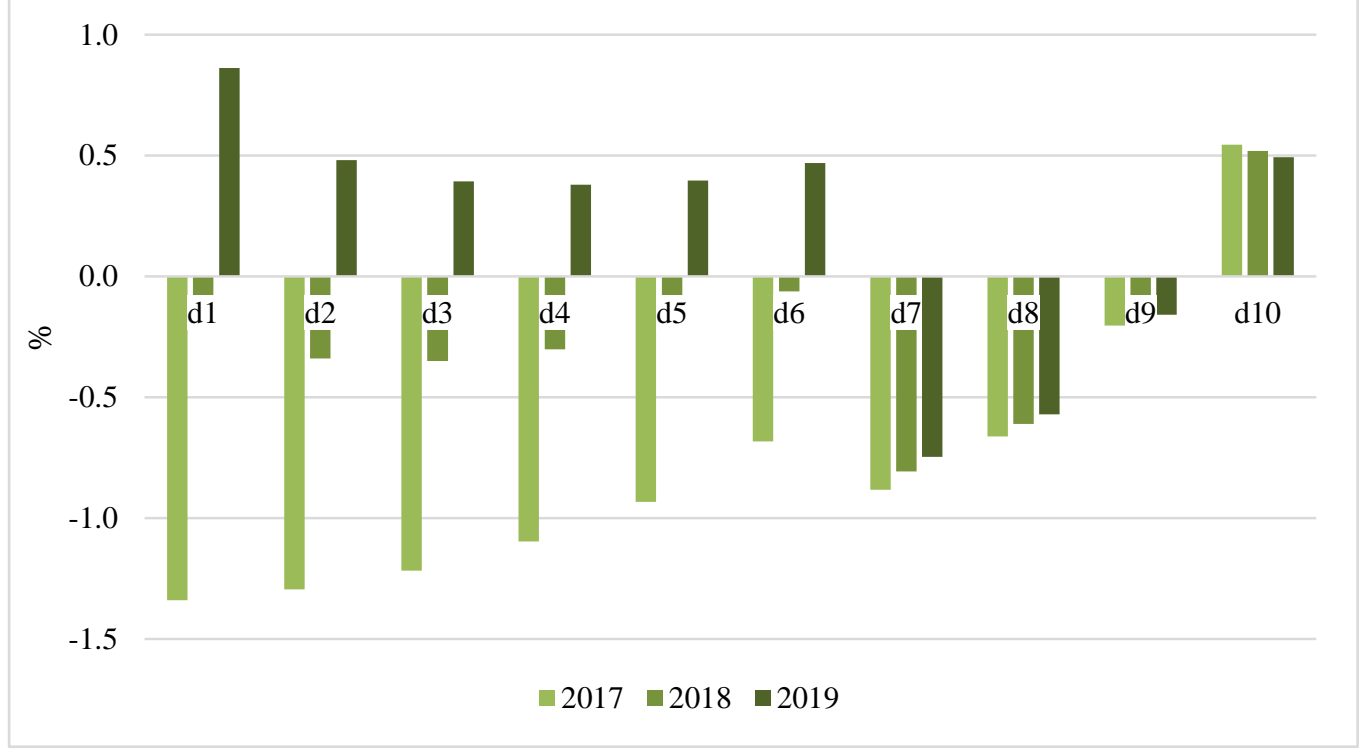

These results, however, should be taken with caution, as there are many barriers and uncertainties associated with the gas-price reform and investments in energy efficiency. While higher energy prices will be immediately passed on to final consumers, it might take some time for energy efficiency investments to be realised. Moreover, the value of the gas subsidy is very uncertain. The estimated rate of the domestic gas subsidy equals approximately $40 \%$, whose elimination could increase government revenues by $\$ 14$ billion per year. A lower value of the domestic gas subsidy would induce less cost-savings, and hence, less public funds would be available for investments in energy efficiency. Moreover, the value of investment costs is also uncertain. Our calculations based on World Bank and IFC (2014) reveal that the investment required to achieve a reduction in energy consumption in buildings of $42 \%$ could account for \$59-118 billion. For the core policy simulations, we took a value of $\$ 90$ billion. Certainly, assuming a higher investment cost (i.e., a pessimistic scenario) implies that it would take a longer period and require more funds to realise the energy saving potential of buildings. Fig. 10 shows that the welfare effects by income decile when the investment cost required to achieve a reduction in energy efficiency of $42 \%$ is assumed to be $\$ 118$ billion. 
Fig. 10. Percentage changes of total private consumption by income decile compared to the reference scenario in 2017, 2018, and 2019 under higher investments costs.

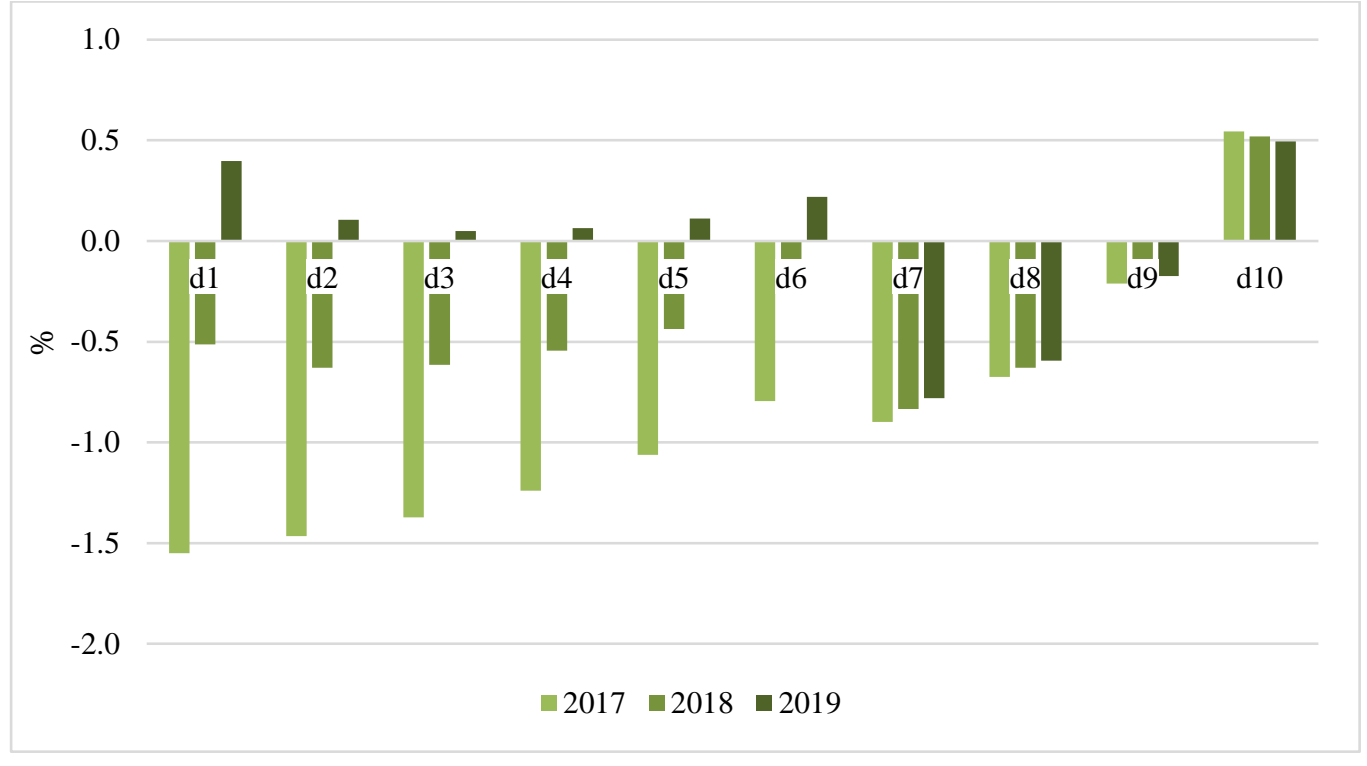

Alternatively, a hybrid revenue-recycling strategy could be implemented, where a part of additional government revenues is used to increase the income of low- and middle-income households and the remainder of revenues is earmarked for investments in the energy efficiency of buildings. Furthermore, in our core policy simulations, the domestic gas subsidy of $40 \%$ is eliminated in 2017. In reality, the regulated domestic gas price could be gradually increased, e.g., a gradual increase in the consumer gas price of $10 \%$, so that adverse effects of the gasprice reform would be moderate in the "IEE of building” scenario.

\section{Income inequality}

Table 5 reveals the changes in income inequality measured by different indexes of income distribution. The impacts of the gas-price reform on income inequality are rather moderate. In the "Transfers" scenario, the Kakwani index is slightly positive due to a reduction in the Gini index, which implies that the welfare gain from the gas-price reform is distributed in favour of poor households. An increase in the Suits index also reveals a progressive impact of the gasprice reform on income distribution. Although in the "IEE of buildings" scenario in 2017 and 2018, the Kakwani index is negative and the Suits index decreases, in 2019, investing in the energy efficiency of buildings would lead to increases in total private consumption of low- and middle-income households, thereby reducing income inequality. Overall, the "Transfers" revenue-recycling policy outperforms the "IEE of buildings" in terms of income distribution, as investments in energy efficiency are costly. However, using additional government revenues 
to invest in the energy efficiency of buildings results in a larger reduction in GHG emissions (see Table 4). This emphasises the trade-off between efficiency and income equity of the gasprice reform.

Table 5. Effects on income inequality.

\begin{tabular}{lccc}
\hline & Initial & Transfers & $\begin{array}{c}\text { IEE of } \\
\text { buildings }\end{array}$ \\
\hline Gini index: & 0.408 & 0.406 & 0.412 \\
2017 & 0.407 & 0.405 & 0.409 \\
2018 & 0.406 & 0.404 & 0.406 \\
\hline 2019 & & & \\
Kakwani index: & & 0.002 & -0.003 \\
2017 & & 0.002 & -0.001 \\
2018 & & 0.002 & 0.000 \\
\hline Suits index: & & & \\
2017 & 0.063 & 0.065 & 0.060 \\
2018 & 0.063 & 0.065 & 0.062 \\
2019 & 0.064 & 0.065 & 0.064 \\
\hline
\end{tabular}

\section{Taxation in the gas sector}

As discussed above, the value of the gas subsidy might be overestimated, while investment costs in energy efficiency might be underestimated. This implies that the Russian government might not have a sufficient amount of funds to realise the energy saving potential of buildings in the short term. At the same time, increasing the regulated domestic gas price could result in the so-called windfall profit for Russia's non-Gazprom producers of gas. To further raise government revenues, the Russian government might consider increasing taxation in the gas sector (i.e., a higher capital gains tax, or corporate income tax, or mineral extraction tax, or a cash-flow tax), which will capture the windfall profit of non-Gazprom producers. Fig. 11 shows the changes of total private consumption by income decile resulting from the gas-price reform supplemented by an increase in the capital gains tax by 30 percentage points. 
Fig. 11. Percentage changes of total private consumption by income decile under the gas-price reform supplemented by an increase in the capital gains tax by 30 percentage points: Deviations from the reference scenario in 2017.

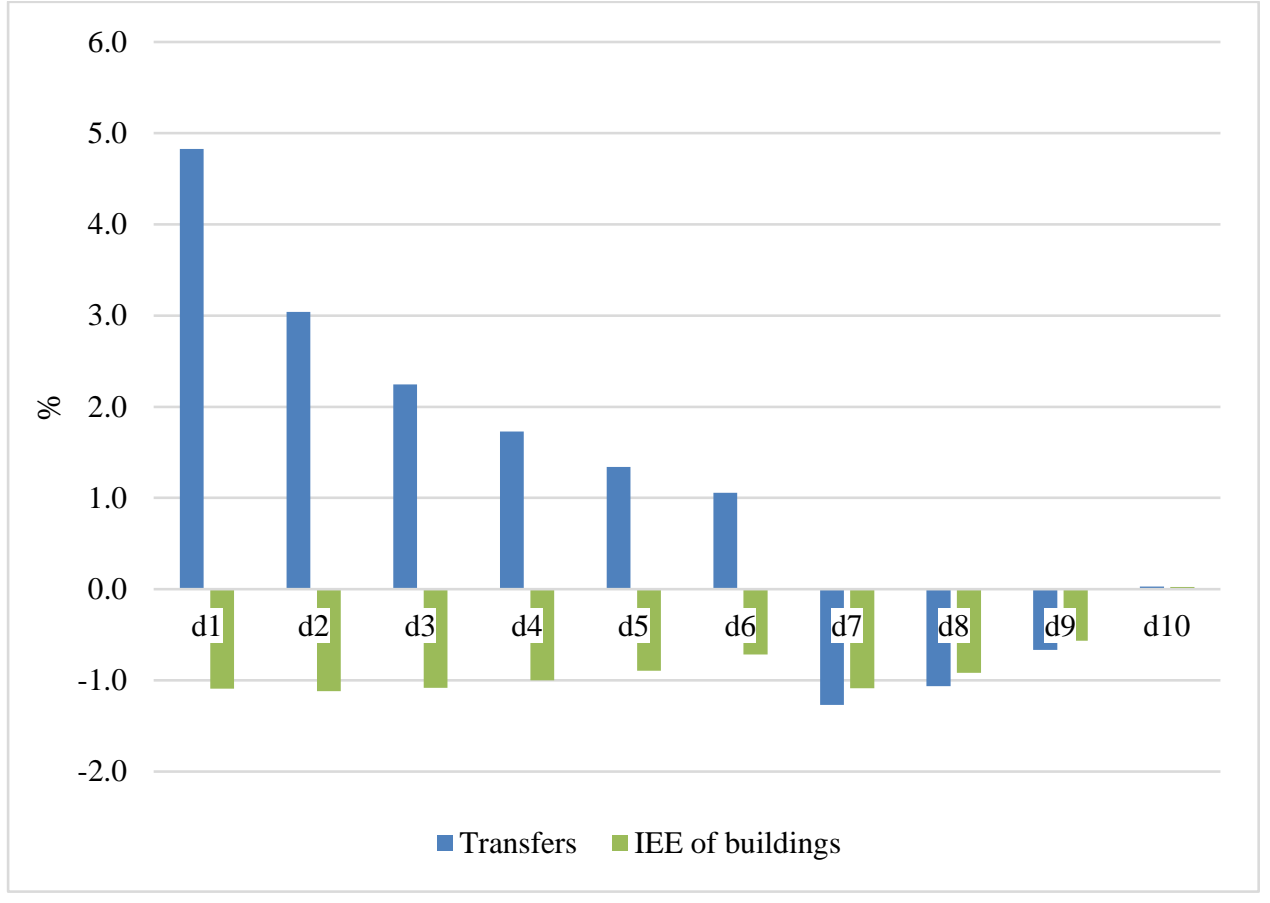

The results from policy simulations show that increasing the capital gains tax in the gas sector further raises government revenues by approximately $\$ 5$ billion per year, which could be used to increase the income of low- and middle-income households or to invest in energy efficiency. As a result, in "Transfers" scenario, the increases in total private consumption by low- and middle-income households become stronger. For example, the total private consumption of the poorest income decile increases by almost 5\%, while the total private consumption of the richest income decile does not change significantly. Moreover, in the "IEE of buildings" scenario, the adverse impacts on poor households are less pronounced in 2017.

\subsection{Sensitivity analyses}

\section{International capital mobility}

In our core policy simulations, we assumed no capital mobility across borders. In reality, capital is neither perfectly mobile nor perfectly immobile. It is likely that capital mobility could affect income distribution among households. Although there are inertias and barriers on capital markets, these tend to diminish in the long term. To investigate how the results from policy simulations are sensitive to the assumption of international capital mobility, we conducted the same policy simulations, while assuming capital mobility across borders. Fig. 12 shows the 
deviations of changes in total private consumption by income decile under international capital mobility from the core results.

Fig. 12. Deviations of changes in total private consumption by income decile under international capital mobility from the core results in 2017.

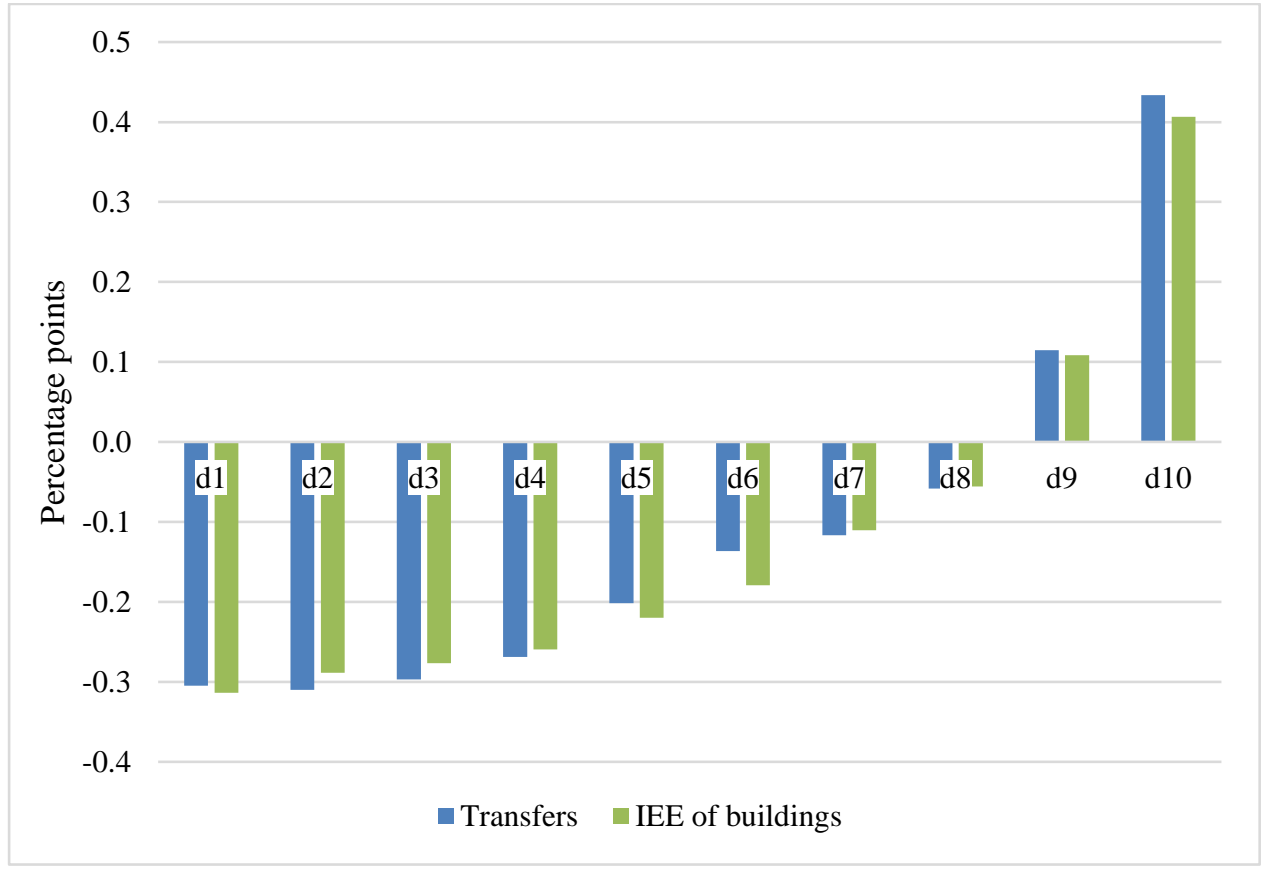

Given the assumption of international capital mobility, the increases in the total private consumption of low- and middle-income households become smaller, while wealthy households benefit more. For example, under international capital mobility, the changes in total private consumption of the poorest income decile are smaller by 0.3 percentage points, whereas for the richest income decile, these are larger by approximately 0.4 percentage points than under capital immobility. Due to capital outflow, the gas-price reform does not result in a decline in the return to capital, whereas the reductions in the wages for skilled and unskilled labour become larger than under capital immobility. For the same reason, in the "IEE of buildings” scenario, low- and middle-income households are more adversely affected by the gas-price reform in the first year, when international capital mobility is assumed.

\section{Substitution elasticity among power generation technologies}

The largest domestic consumer of gas in Russia is the power generation sector. Hence, the demand elasticity of gas by the power generation sector has a significant impact on the results. The substitution elasticity among different power technologies determines the price elasticity of gas demand by the power generation sector as well as the supply elasticity of power 
generation. The core value of the substitution elasticity is assumed to equal 1.4. For this sensitivity analysis, we increased (decreased) the value of the substitution elasticity by $50 \%$. Assuming a higher (lower) value of the substitution elasticity among power generation technologies substantially increases (decreases) the welfare gain from the gas-price reform (Fig. 13). For example, in the "Transfers" scenario under a substitution elasticity of 2.1, the increase in total private consumption of the poorest income decile is larger by 0.6 percentage points than under the core value. A higher (lower) value of the substitution elasticity leads to a smaller (larger) increase in the producer price of power generation, thereby diminishing (exacerbating) the adverse impacts on households and industry.

Fig. 13. Deviations of changes of total private consumption by income decile under a substitution elasticity of 2.1 from the core results in 2017.

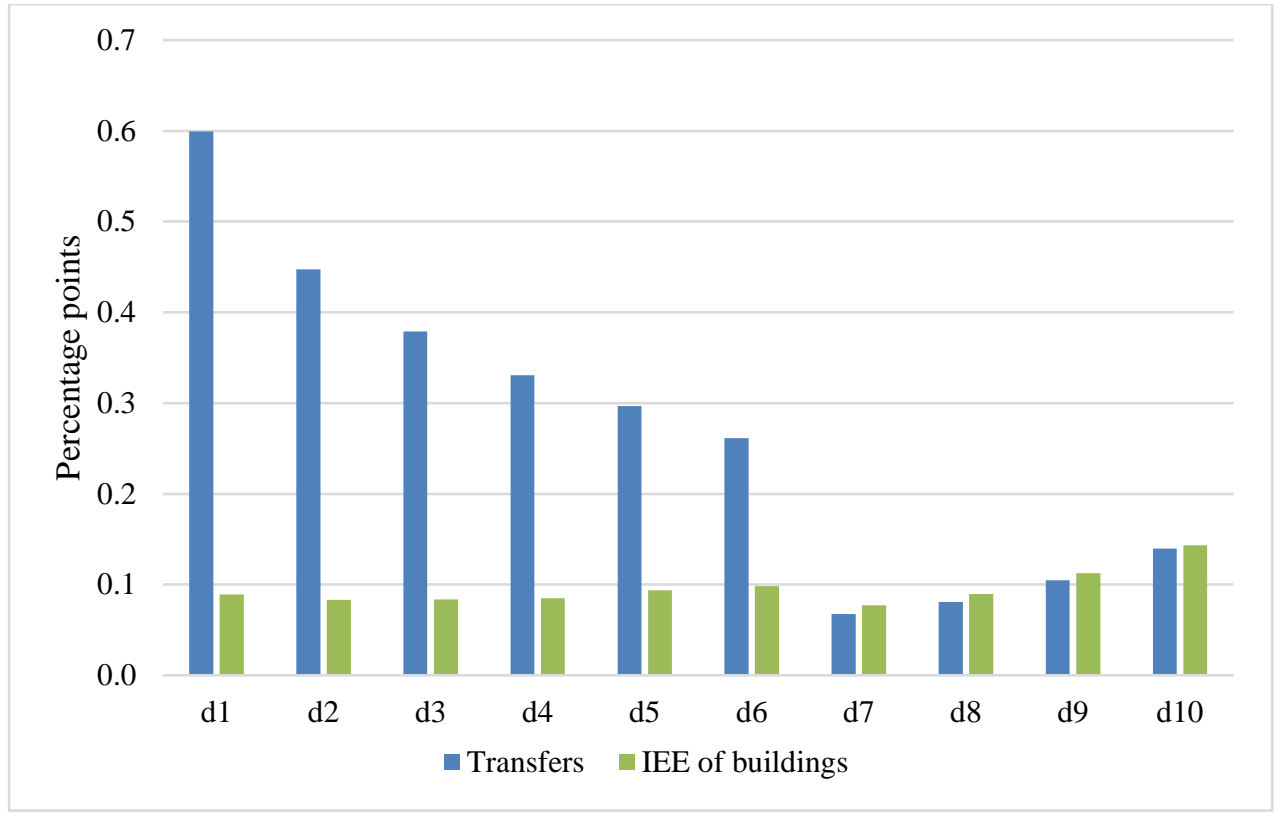

\section{Supply and households' demand elasticities for gas}

The values of compensated own-price and income elasticities of demand for gas in Russia are assumed to equal -0.41 and 0.35 , respectively. These values were estimated by using a paneldata regression model. The price elasticity of gas supply is assumed to equal 1 . The values of demand and supply elasticities for gas are also uncertain. To investigate how strongly the results from policy simulations are affected by different values of demand and supply elasticities for gas, we conducted the same policy simulations but increasing (decreasing) the core values of supply and households' demand elasticities for gas by $50 \%$. The results from sensitivity analyses show that different values of supply elasticity and households' demand 
elasticities for gas in Russia do not have a significant impact on the results, i.e., the changes in total private consumption by income decile are very similar compared to the core results. On average, the differences in the results (i.e., the changes in Russia's private welfare) account for approximately 0.01 percentage points. Under a higher (lower) value of the price elasticity of households' demand for gas and/or a higher (lower) value of the income elasticity, Russia's private welfare gains from the gas-price reform are slightly larger (smaller). Furthermore, assuming a higher (lower) value of the price elasticity of gas supply in Russia leads to a smaller (larger) welfare gain. In contrast, setting different values of the price elasticity of gas supply in the RoW has a significant impact on the results. For example, increasing the supply elasticity for gas in the RoW by 50\% increases Russia's private welfare gains by approximately 0.09 percentage points.

\section{Conclusions and policy implications}

Domestic prices for natural gas are regulated in Russia and they are substantially lower than export netback prices. Such a price regulation operates as an implicit gas subsidy. The objective of this paper was to analyse the income distributional effects of the abolishment of the implicit domestic gas subsidy in Russia. Our analysis was based on a dynamic, multi-region, multisector CGE model with multiple household groups and a detailed power generation sector.

It is found that eliminating the implicit gas subsidy leads to an overall welfare gain in Russia. Intuitively, the elimination of a distortionary subsidy tends to enhance the economic efficiency. However, increasing the regulated domestic gas price in Russia could induce a strong adverse impact on poor households, as they spend a larger share of their income on gas, electricity, and heating than wealthy households do. Nevertheless, using additional government revenues from increased gas prices to raise the income of low- and middle-income households could offset the adverse impact of increased energy prices and increase private welfare of these household income groups. The results from policy simulations show that total private consumption of the poorest income decile could increase by almost 3\%. Moreover, increasing the regulated domestic gas price results in a significant reduction in GHG emissions due to a lower gas consumption: for example in 2017, Russia’s total GHG emissions could decrease by 177 million tonnes (Mt) of $\mathrm{CO}_{2}$ equivalent.

While using additional government revenues to increase the income of poor households is effective in alleviating the adverse redistributive effects of higher energy prices, it is likely that 
the most efficient revenue-recycling policy would be to invest in energy efficiency. Russia has a large energy savings potential, in particular in residential and public buildings. The results from policy simulations reveal that investing in the energy efficiency of buildings results in a much larger reduction in GHG emissions compared to that when revenues are returned to households in a lump-sum form. For example in 2019, the annual reduction in GHG emissions would account for $232 \mathrm{Mt}$ of $\mathrm{CO}_{2}$ equivalent. Increasing the regulated domestic gas price could increase government revenues by approximately $\$ 14$ billion per year, while to achieve a reduction in energy consumption in buildings of $42 \%$, an investment of $\$ 90$ billion might be required. In the short term, annual additional government revenues could be insufficient to fully realise the energy savings potential and to offset the increase in energy prices, i.e., short-term adverse impacts on poor households might occur. For example in 2017, total private consumption of the poorest income decile could decrease by $1.3 \%$. Nevertheless, in subsequent years, investing further in the energy efficiency of buildings could offset the adverse effects of increased energy prices. The results from policy simulations show that, in 2019, total private consumption of the poorest income decile could increase by almost $1 \%$. To overcome the problem related to the short-term adverse impacts on poor households, it might be rational to implement a hybrid revenue-recycling policy, where a part of additional revenues would be used to invest in the energy efficiency of buildings and the remainder of revenues would be transferred to low- and middle-income households. Furthermore, an increase in regulated domestic gas prices should be gradually implemented.

The results from policy simulations should be taken with caution because the value of the domestic subsidy and investment costs in energy efficiency are uncertain. Assuming a higher investment cost and/or lower government revenues from increasing domestic gas prices would imply that more funds would be required to realise the energy saving potential. At the same time, increasing the regulated domestic gas price could lead to windfall profits for nonGazprom producers. To further raise government revenues and thereby to increase the effectiveness of the gas-price reform, the Russian government could supplement an increase in the domestic gas price by an increase the production or income tax in the gas sector. The results from policy simulations show that an increase in the capital income tax in Russia's gas sector by 30 percentage points could further increase government revenues by approximately $\$ 5$ billion per year by capturing windfall profits. In addition, some funds from Russia's sovereign wealth funds could be used for investments in energy efficiency. Although our analysis focuses 
on natural gas, it is worth mentioning that increasing the regulated domestic gas price would lead to an increase in the consumption of coal. To prevent this and to further increase government revenues, it might be rational to proportionally increase the tax on coal consumption or extraction.

Furthermore, we should emphasise uncertainties related to the model structure, and parameterisation and calibration of the model. The sensitivity analyses reveal that results from policy simulations are very sensitive to different values of the price elasticity of gas supply in the RoW and the substitution elasticity among power generation technologies in Russia. A higher (lower) value of the supply elasticity of gas and/or a higher (lower) value of the substitution elasticity among power generation technologies would lead to a larger (smaller) welfare gains and a larger (smaller) reduction in GHG emissions in Russia. Moreover, given the assumption of international capital mobility, poor (rich) households would be more (less) adversely affected by the gas-price reform.

Finally but importantly, we should emphasise that communication of the gas-price reform to the population might be as important as its implementation. It is of crucial importance to obtain public support by explaining the relevance, main purposes, and earmarking mechanisms behind the gas-price reform.

\section{References}

Aaheim, H. A. and Rive, N. (2005). A Model for Global Responses to Anthropogenic Changes in the Environment (GRACE). Report. Oslo, Norway, CICERO. 2005:05.

Aguiar, A., Narayanan, B., McDougall, R., 2016. An overview of the GTAP 9 data base. Journal of Global Economic Analysis 1(1), 181-208.

Aguiar, A., Narayanan, B., McDougall, R., 2016. An overview of the GTAP 9 data base. Journal of Global Economic Analysis 1(1), 181-208.

Bashmakov, I., 2009. Resource of energy efficiency in Russia: scale, costs, and benefits. Energy Efficiency 2:369.

Bashmakov, I., Myshak, A., 2014. Russian energy efficiency accounting system. Energy Efficiency 7, 743-759.

Ersado, L., 2012. Poverty and distributional impact of gas price hike in Armenia. The World Bank Policy Research Working Paper No. 6150.

Federal State Statistics Service (FSSS), 2016a. Basic consumer price indexes. Available at: https://www.fedstat.ru/indicators/search?searchText=\%D0\%B8\%D0\%BD\%D1\%84\%D0\%BB\%D1\%8F\%D1 $\% 86 \%$ D0\%B8\% $1 \% 8 \mathrm{~F}$

Federal State Statistics Service, 2016. Income, expenditure and consumption of households. Available at: http://www.gks.ru/wps/wcm/connect/rosstat_main/rosstat/ru/statistics/publications/catalog/doc 1140096812 $\underline{812}$

Felder, S., van Nieuwkoop, R. 1996. Revenue recycling of a CO2 tax: Results from a general equilibrium model for Switzerland. Annals of Operations Research 68(2), pp 233-265. 
Feng, K., Hubacek, K., Guan, D., Contestabile M., Minx, J., Barrett, J., 2010. Distributional effects of climate change taxation: the case of the UK. Environ. Sci. Technol. Lett. 44, 3670-6.

Gazprom, 2014. Investors. Gazprom in Figures 2009-2013. Gas sales. Available at: http://www.gazprom.com/investors/reports/2013/

Gazprom, 2015. Investors. Information disclosure. Gazprom in Figures 2011-2015. Available at: http://www.gazprom.com/investors/disclosure/reports/2015/

Heyndrickx, C., Alexeeva-Talebi, V., Tourdyeva, N., 2012. To Raise or Not to Raise? Impact Assessment of Russia’s Incremental Gas Price Reform. Discussion Paper No. 12-052.

IEA, 2016. Statistics. Available

at: https://www.iea.org/statistics/statisticssearch/report/?country=RUSSIA\&product=indicators\&year=2011

Krauss, A., 2016. How natural gas tariff increases can influence poverty: Results, measurement constraints and bias. Energy Economics 60, 244-254.

Ministry of Finance of Russia, 2016. Russia’s sovereign welfare fund. Available

at: http://minfin.ru/ru/perfomance/nationalwealthfund/statistics/

OECD/IEA, 2015. World Energy Outlook 2015. Available

at: http://www.worldenergyoutlook.org/resources/energysubsidies/fossilfuelsubsidydatabase/

Peters, J.C., 2016. The GTAP-Power database: Disaggregating the electricity sector in the GTAP database. Journal of Global Economic Analysis 1(1), 209-250.

Rutherford, T., Tarr, D., Shepotylo, O., 2004. Poverty Effects of Russia’s WTO Accession: modeling “real” households and endogenous productivity effects.

Sterner, T., 2012 (ed.). Fuel taxes and the poor: The distributional consequences of gasoline taxation and their implications for climate policy. RFF Press, Routledge. ISBN 978-1-61726-092-6.

Stockfisch, J., 2007. The income distribution effects of a natural gas price increase. Contemporary Economic Policy 1(1), 9-26.

The Russian Government, 2010. Government Decree No.1205 from December 31, 2010. In: ConsultantPlus. Available

at: http://base.consultant.ru/cons/cgi/online.cgi?req=doc;base=LAW;n=162054;fld=134;dst=4294967295;rnd=0. $\underline{1672593537024063 ; \text { from }=110851-6}$

Wang, Q., Hubacek, K., Feng, K., Wei, Y-M., Liang, Q-M., 2016. Distributional effects of carbon taxation. Applied Energy 184, p. 1123-1131.

Williams, R., Gordon, H., Burtraw, D., Carbone, J., Morgensten, R., 2014. The initial incidence of a carbon tax across income groups. RFF Discussion Paper 14-24.

World Bank and IFC, 2014. Energy efficiency in Russia: untapped reserves. The World Bank Working Paper No. 91503. Available at: http://documents.worldbank.org/curated/en/750871468307169609/Energy-efficiencyin-Russia-untapped-reserves 